(C) Dr.W. Junk Publishers, Dordrecht. Printed in the Netherlands.

\title{
Bacteria and phosphorus regeneration in lakes. An experimental study
}

\author{
Urs Uehlinger
}

Institute of Aquatic Sciences (EAWAG), Swiss Federal Institute of Technology (ETH), Ueberlandstrasse 133, CH-8600 Dübendorf, Switzerland

Keywords: bacteria, phosphorus, nutrient regeneration, algae, cultures

\begin{abstract}
The aerobic decomposition of the green alga Chlamydomonas reinhardii by a mixed population of lake bacteria was studied in batch and chemostat cultures. Bacterial chemostats were supplied with continuously heatkilled algae. The dead algae rapidly released most of their phosphorus as SRP. In the batch experiments bacteria acted as consumers of the released algal phosphorus. This phosphorus uptake was dependent on the $\mathrm{C}: \mathrm{P}$ ratio of the algae. During the death phase of the bacteria most of the bacterial phosphorus itself was released. The continuous supply of energy in form of dead algae in the chemostat experiments prevented the death phase of the bacteria and thus any net regeneration of phosphorus. The influence of the C:P stoichiometry of algae and bacteria on the regeneration of algal phosphorus is discussed.
\end{abstract}

\section{Introduction}

Nutrient regeneration is by definition the release of nutrients fixed in organisms, for reuse by primary producers. In lakes, this process takes place mainly in the epilimnion. Bloesch et al. (1977) estimated that in a mesotrophic lake 67 percent of the phosphorus, which is required to maintain the measured primary production, is supplied by the epilimnetic nutrient regeneration.

Several mechanisms participate in this process. Zooplankton release the nutrients of their food by excretion and defecation (Peters \& Rigler, 1973). Enzymes (phosphatases) split the monoester bonds of organic phosphorus compounds (Reichardt, 1971). Dead organisms are subject to autolysis induced by uncontrolled biochemical reactions of lytic enzymes releasing SRP (Golterman, 1973). The role of bacteria in nutrient regeneration is still debated. According to DePinto \& Verhoff (1977) bacteria must be present to release orthophosphate and ammonia from dead algae. On the other hand Johannes (1968) postulated that the zooplankton contributes by much more to the nutrient regeneration than do the bacteria. Moreover, Stöckli (1985a) showed that a natural bacterial population did not mineralize organic phosphorus; but rather formed refractory phosphorus compounds which could not be used by algae.

The aim of this study is to show whether and how bacteria participate in the phosphorus regeneration with respect to the epilimnetic phosphorus cycle. For this purpose the fate of algal phosphorus during the aerobic bacterial decomposition of the green alga Chlamydomonas reinhardii has been investigated. The experiments were carried out either in batch or chemostat culture systems. Soluble reactive phosphorus (SRP) was assumed to be the regenerated form of algal phosphorus (this assumption is supported by results of algal bioassays performed in a similiar experimental system, Stöckli, 1985b).

\section{Methods}

Algae

An axenic strain of the green alga Chlamydomo- 
nas reinhardii Danegard (No. $11-32 \mathrm{a}$ from the algae collection of the University of Göttingen, West Germany) was grown in a chemostat system (Hirsbrunner, 1981). The culture was aerated with sterile air enriched with $\mathrm{CO}_{2}(0.3 \%)$. The light intensity at the surface of the culture vessel was about $150 \mu \mathrm{E} \cdot \mathrm{m}^{-2} \cdot \mathrm{S}^{-1} \cdot \mathrm{Z}$ solution (Staub, 1961) and KGFS medium (Stöckli, 1985b) were used as culture media. Phosphate and nitrate concentrations were varied according to the experimental requirements.

\section{Microorganisms}

Bacteria from the eutrophic Greifensee were used in all experiments. Water from $1 \mathrm{~m}$ depth was filtered by a sterile Nitex screen (mesh size $8 \mu \mathrm{m}$ ) to prevent the contamination of the culture vessels with protozoa. About 20 to $50 \mathrm{ml}$ of this filtrate were used as inoculum. Growth of small phototrophic organisms (picoplankton) which also may have passed the $8 \mu \mathrm{m}$ screen has never been observed in any experiment.

\section{Batch experiments}

At the beginning of an experiment the glass vessels (volume 2 or 15 liters) were filled with sterile KGFS medium free of phosphorus and combined nitrogen, and subsequently dead algae (killed by heating at $60^{\circ} \mathrm{C}$ for at least 45 minutes) and a viable inoculum of bacteria were added.

\section{Chemostat experiments (Fig. 1)}

The suspension of axenic algae was introduced into a mixing vessel by passage through a glass he-

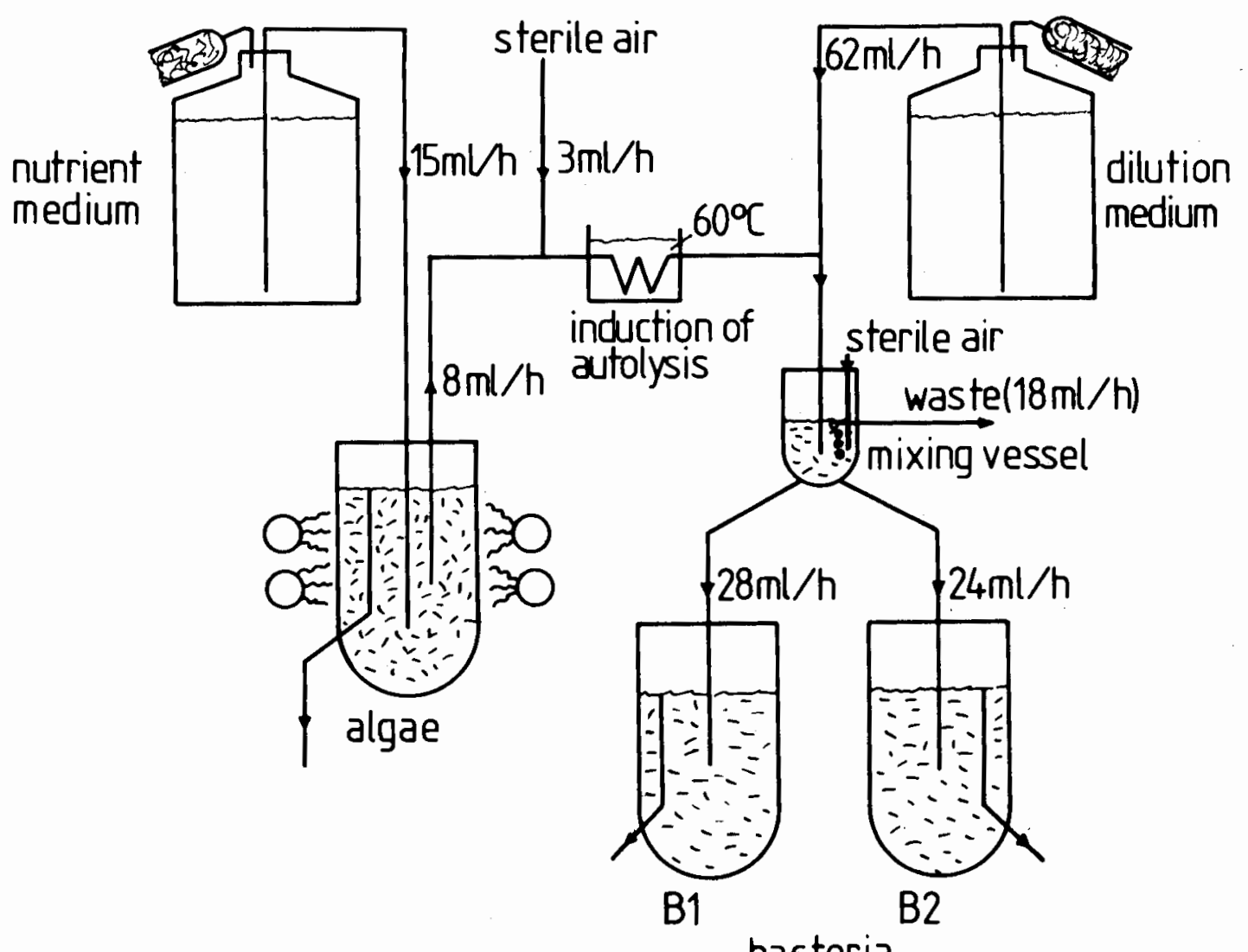

Fig. 1. Schematic diagram of the chemostat system. Algae chemostat: Volume $=2010 \mathrm{ml}$; dilution rate $=0.0074 \mathrm{~h}^{-1}$. Bacteria chemostats: volumes of $\mathrm{B} 1$ and $\mathrm{B} 2=2000 \mathrm{ml}$ each; dilution rates of $\mathrm{B} 1$ and $\mathrm{B} 2$ are 0.014 and $0.012 \mathrm{~h}^{-1}$, respectively. 
lix (residence time 45 minutes) which was situated in a water bath at $60^{\circ} \mathrm{C}$, to kill the algal cells. The algal suspension was segmented with sterile air to prevent sedimentation in the helix. The suspension of the dead algae was diluted in the mixing vessel with sterile KGFS medium (without phosphorus and combined nitrogen), homogeneized by bubbling with sterile air and pumped into the bacterial culture growing in the chemostats. The dilution rates of the two bacterial chemostats $\mathrm{B} 1$ and $\mathrm{B} 2$ were similiar, 0.014 and $0.012 \mathrm{~h}^{-1}$, respectively.

Batch and chemostat vessels were aerated with sterile air. To inhibit the growth of the algae, introduced by the inoculum, batch and chemostat cultures were set up in dim light. To minimize wall growth the cultures were stirred with magnetic stirrers, and the walls of the chemostat vessels have been scraped bi-daily with the stirrer bar. The incubation temperature was $23^{\circ} \mathrm{C}$ if not otherwise stated.

\section{Bacteriological methods}

Bacterial cells were directly counted after staining with acridine orange in an epifluoresence microscope (Acridine Orange Direct Counts = $A O D C$, Overbeck, 1977). Colony Forming Units = $C F U$ were grown on trypton glucose extract agar = TGE agar (Bührer, 1979). $10 \mathrm{ml}$ TGE agar were melted, cooled down to $44^{\circ} \mathrm{C}$ and mixed with $1 \mathrm{ml}$ of sample; the plates were incubated for 5 days at $20^{\circ} \mathrm{C}$. In order to characterize the bacteriacl population physiological groups were determined with the most probable number (MPN) method (Reichardt, 1978). Per dilution (dilution steps 1:10) 5 parallel test tubes with $10 \mathrm{ml}$ media were used. The following groups (Plüss, 1978) were determined: proteolytic bacteria (gelatine decomposers), polysaccharid decomposers, ammonia producers, phosphatase producers.

\section{Chemical parameters}

Soluble reactive phosphorus (SRP) was determined according to Vogler (1965). Total phosphorus in unfiltered water (TP) and total phosphorus in membrane $(0.45 \mu \mathrm{m})$ filtered samples (TPF) were determined as SRP after digestion with $\mathrm{K}_{2} \mathrm{~S}_{2} \mathrm{O}_{8}$ (EAWAG manual, unpublished). Total organic carbon (TOC) and dissolved organic carbon (DOC) were analyzed with a Beckman TOC-Analyzer 915.

\section{Results}

\section{Batch experiments}

Killing Chlamydomonas cells by heat caused a fast release of SRP. Within 60 minutes about $50 \%$ of the phosphorus fixed in the algae was released as SRP increasing to $80 \%$ after 4 days. The amount of the soluble unreactive phospohorus (TPF minus SRP) decreased until the fourth day and finally was 10 to $15 \%$ of the TP (Fig. 2). The corresponding loss of dry weight biomass amounted to 8 to $12 \%$ one hour after the heat treatment.

The presence of bacteria remarkably changed the dynamics of phosphorus release (Fig. 3). After a short increase at the beginning of an experiment, the SRP concentration reached a minimum between the second and third day. This minimum coincided with the maximum of the bacterial population. The TPF showed a similiar pattern. Between 55 and $84 \%$ of the phosphorus which was released by autolysis were immobilized by the bacteria (Table 1). The relative amount of the phosphorus taken up increased with increasing $C: P$ ratio of the algae. Between the third and fourth day of an experiment the bacteria began to die because of the shortage in energy, and simultaneously SRP and TPF concentrations increased. However, after 12 to 17 days they were lower than at the beginning. Phosphorus release by autolysis, phosphorus uptake by the bacteria and phosphorus release following the decay of the bacterial population were accelerated with increasing temperature (Fig. 4). The TOC decrease paralleled the bacterial phosphorus

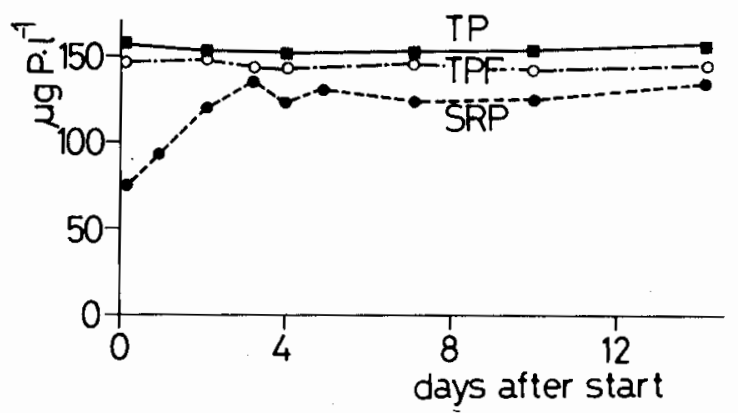

Fig. 2. SRP and TPF concentrations in a control experiment without bacteria. The algae were killed by heat $\left(1\right.$ hour at $\left.60^{\circ} \mathrm{C}\right)$ and immediately transfered to a glass vessel with sterile media which contained no phosphorus and combined nitrogen. The C:P ratio of the algae was 44 . 
experiment 1
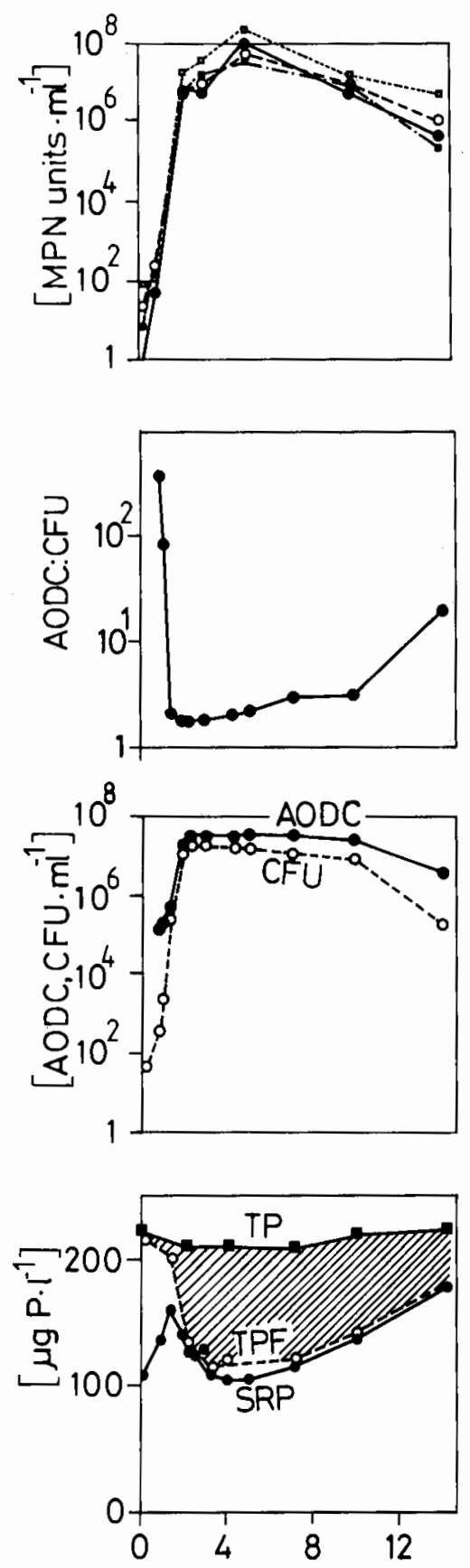

experiment 2
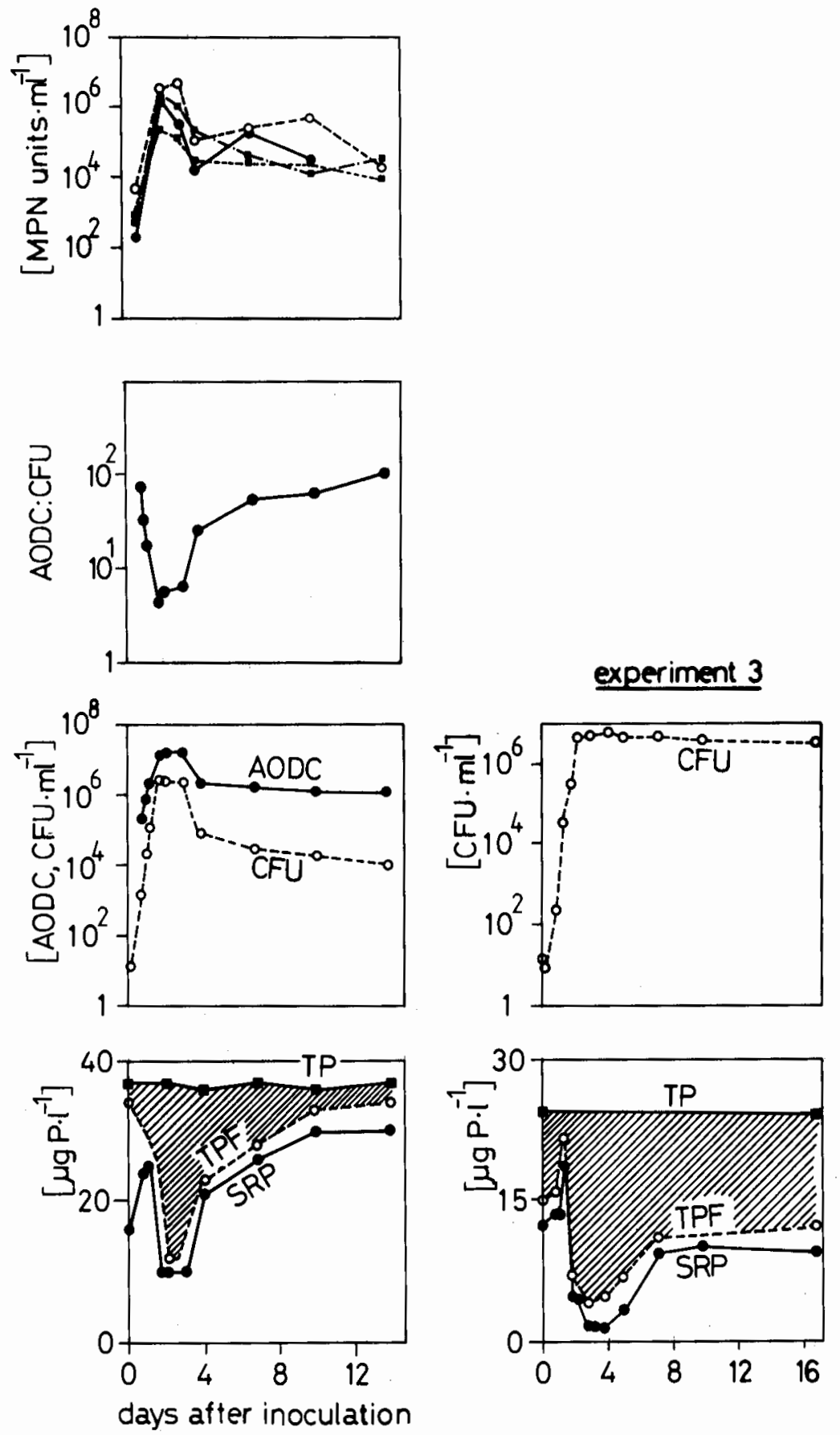

Fig. 3. Batch experiments: First horizontal row, physiological groups, o- o proteolytic bacteria, $\bullet$ polysaccharid decomposers, - ammonia producers, $\square-\mathrm{u}$ phosphatase producers; second row, R = AODC:CFU; third row, AODC and CFU; fourth row, phosphorus fractions, the hatched area corresponds to the particulate phosphorus. The C:P ratio of the algae before killing was 44 in experiment 1,88 in experiment 2 and 330 in experiment 3 . 


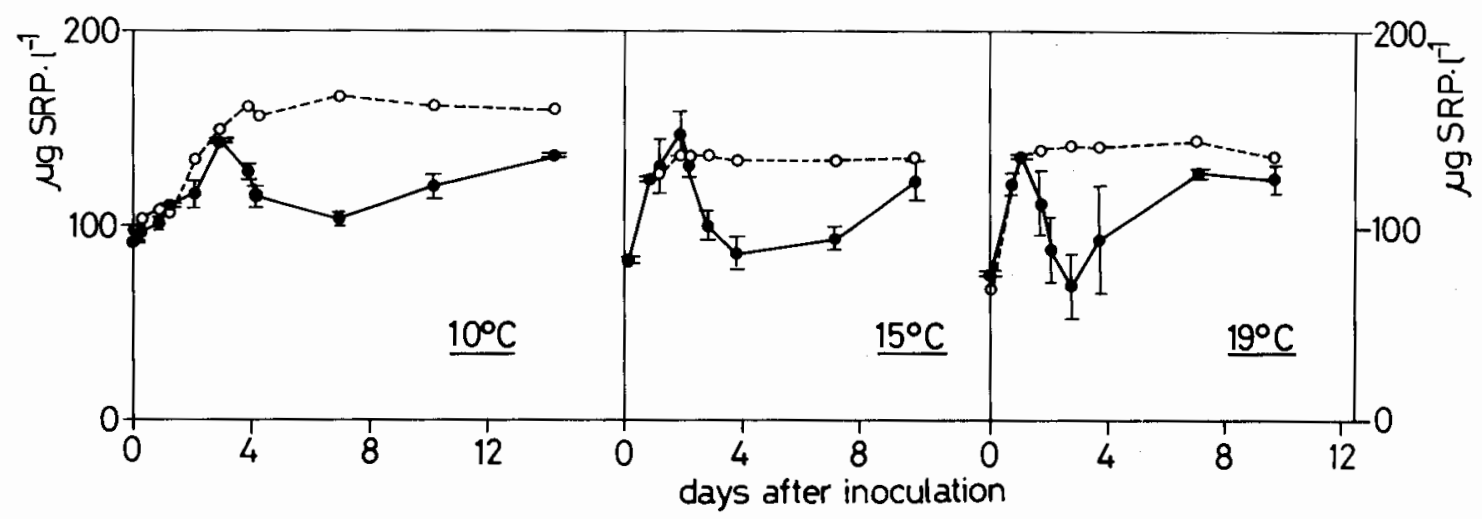

Fig. 4. Batch experiments: The influence of temperature on SRP uptake and release. $I=$ standard deviation $(n=3)$. o-o control experiment without bacteria. - - experiments with bacteria. The C:P ratio of the algae was about 40.

Table 1. Batch experiments: Phosphorus taken up by the bacteria in $\%$ of the maximum TPF at the beginning of an experiment.

\begin{tabular}{lccc}
\hline $\begin{array}{l}\text { C:P (weight) } \\
\text { of the algae }\end{array}$ & 44 & 88 & 330 \\
$\begin{array}{l}\text { Phosphorus } \\
\text { taken up in } \%\end{array}$ & $55 \pm 13$ & $60 \pm 7$ & $84 \pm 4$ \\
$\begin{array}{l}\text { Number of } \\
\text { experiments }\end{array}$ & 5 & 2 & 2 \\
\hline
\end{tabular}

uptake (Fig. 5). At the end of the experiment about $55 \%$ of the TOC were mineralized, whereas the DOC concentration did not change.

The bacterial population (AODC, CFU's, phys-

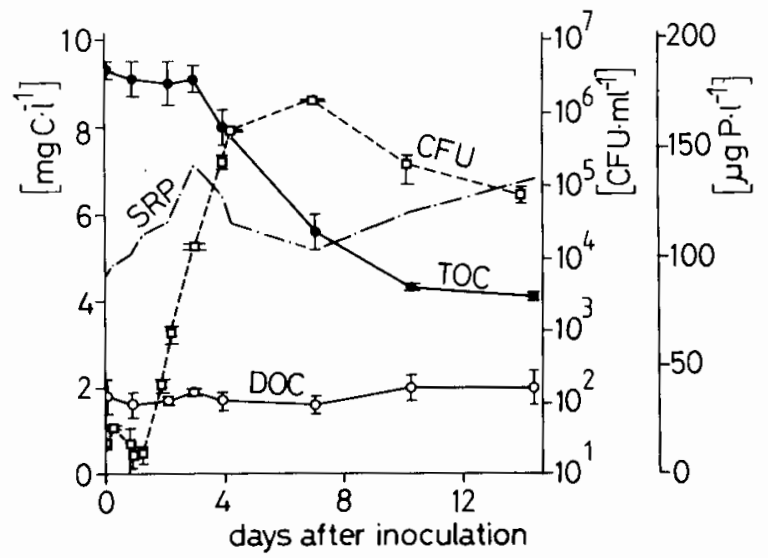

Fig. 5. Batch experiments: Mineralization of organic carbon. The temperature was $10^{\circ} \mathrm{CI}=$ standard deviation $(n=3)$. iological groups) reacted immediately on the nutrient supply. In all batch experiments the typical growth curve with lag, exponential, stationary, and decay phase was more or less pronounced (Figs 3 and 5). During the exponential growth, which lasted 1.5 to 2 days, maximum growth rates calculated from cell counts and CFU's reached about $0.45 \mathrm{~h}^{-1}$ and $0.55 \mathrm{~h}^{-1}$, respectively. In the exponential phase the main part of the bacterial

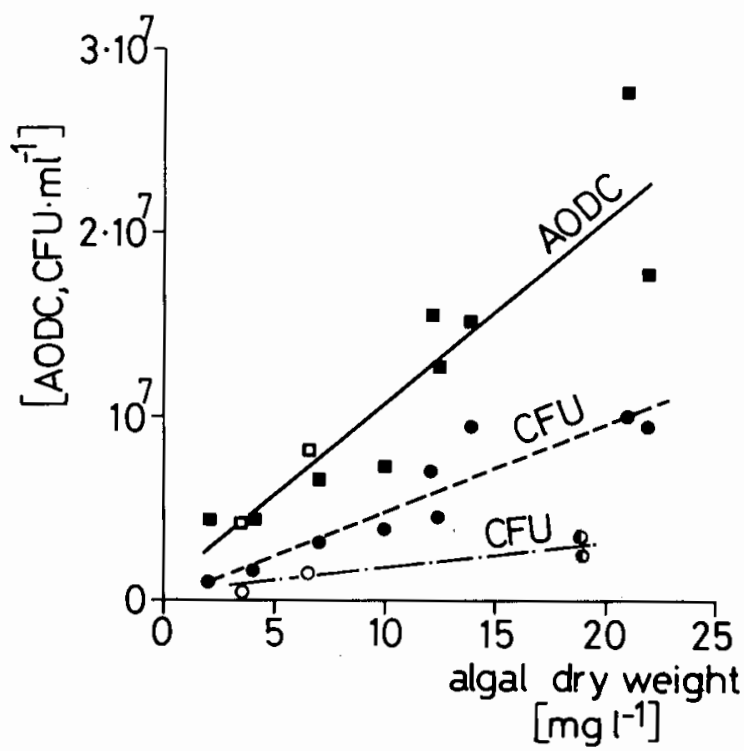

Fig. 6. Batch experiments: Population maxima (AOCD and CFU) of the bacteria as a function of the initial concentration of algal dry weight (taken before heat death). Squares = AODC, - algal C:P ratio $=44 \quad \square=81$. Circles $=C F U$, algal C:P ratio - $=44, \mathrm{O}=81, \circ=330$. 
population was suspended in the medium as single cells. However, in the stationary phase colonies of 30 to more than 100 cells were formed on detritus particles. The number of cells in such colonies could only be estimated. The maximum number of bacteria (AODC) and colonies (CFU) was proportional to the amount of dead algae at the beginning of an experiment (Fig. 6). However, the initial ratio 'maximum number of CFU: concentration of dead algae' decreased with increasing C:P ratio of the algae. Between the second and fourth day the decay of the bacteria started and the CFU's decreased faster than the AODC. The ratio $\mathrm{R}=\mathrm{AODC}$ : $\mathrm{CFU}$ has been considered as an indicator of the supply in waters of organic substrate (Overbeck, 1974). The low values of $R$ which were observed mainly during the stationary phase of an experiment indicate a high supply (Fig. 3).

\section{Chemostat experiments}

Within the first two days after the inoculation of the chemostats, the bacterial population (AODC, CFU) increased exponentially (Fig. 7), and R droped from 180 and 110 , respectively, to less than 10. CFU's and AODC decreased after the third day to a lower level.

The experiment was disturbed by a steady de-

\section{chemostats B1\&B2}
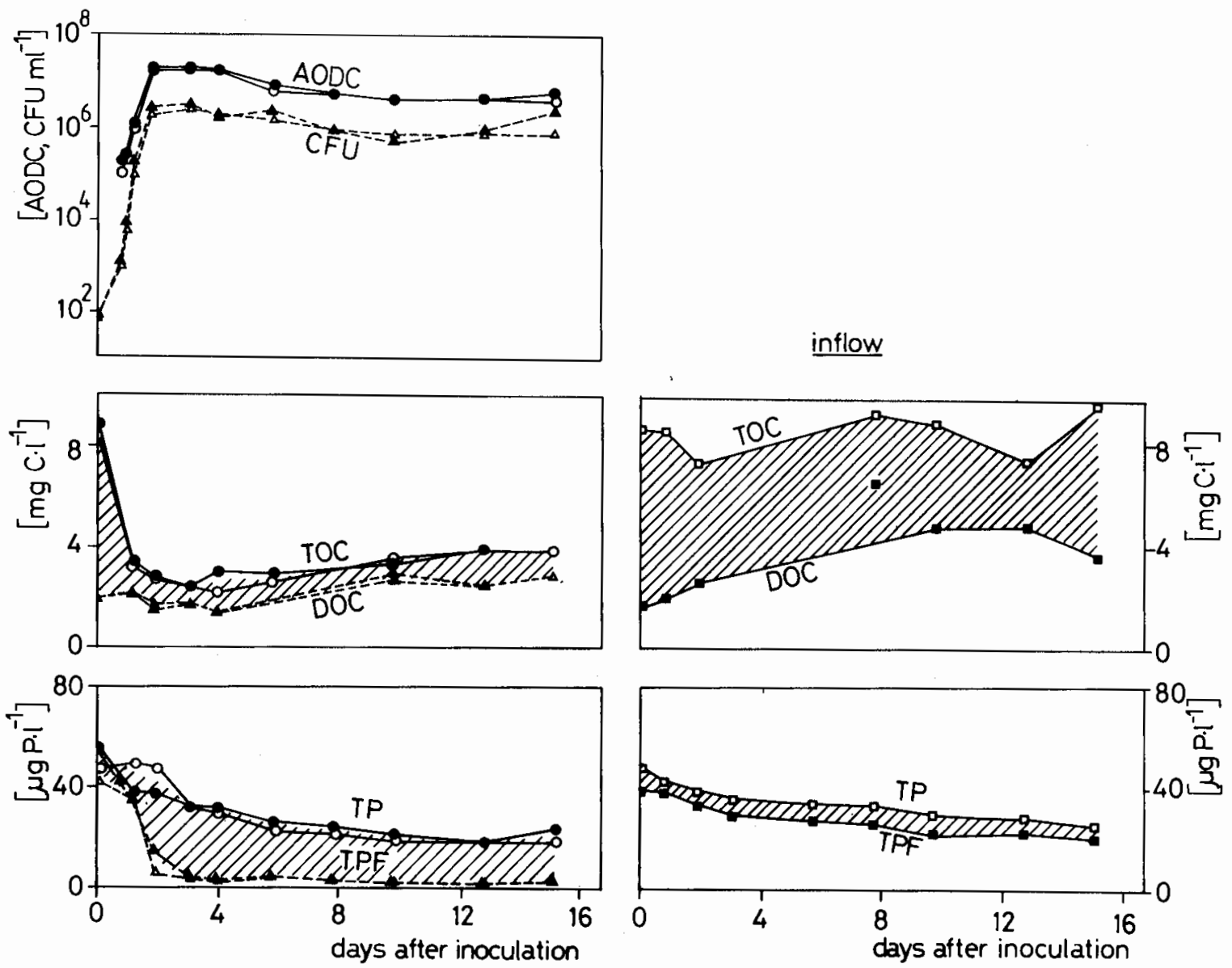

Fig. 7. Chemostat experiment: $\mathrm{P}$ fractions, organic $\mathrm{C}$ fractions, $\mathrm{AODC}$ and $\mathrm{CFU}$. Filled symbols $=$ chemostat $\mathrm{B} 1$, open symbols $=$ chemostat B2. The hatched area corresponds to particulate phosphorus and carbon, respectively. 
Table 2. Chemostat experiment: phosphorus and organic carbon in the chemostats anbd in the inflow to both chemostats (mean values from day 3 after inoculation with bacteria to day 15 in $\mu \mathrm{g} \cdot 1^{-1}$ ).

\begin{tabular}{|c|c|c|c|c|c|c|c|c|c|}
\hline & $\mathrm{TP}$ & TPF & SRP & PP & TOC & $\mathrm{DOC}$ & $\mathrm{POC}$ & $\begin{array}{l}\mathrm{C:P} \\
(\mathrm{TOC} / \mathrm{TP})\end{array}$ & $\begin{array}{l}\mathrm{C}: \mathrm{P} \\
\text { (POC/PP) }\end{array}$ \\
\hline inflow & $30.4 \pm 3.7$ & $23.4 \pm 3.1$ & $19.5 \pm 1.0$ & $6.7 \pm 4.8$ & $8700 \pm 870$ & $4880 \pm 1080$ & $3820 \pm 1390$ & $286 \pm 45$ & $570 \pm 458$ \\
\hline $\begin{array}{l}\text { chemostat } \\
\text { B1 }\end{array}$ & $25.1 \pm 5.2$ & $3.2 \pm 0.9$ & $\begin{array}{c}1.5 \pm 1.2 \\
(0.6 \pm 0.1)^{*}\end{array}$ & $21.9 \pm 5.3$ & $3100 \pm 552$ & $2080 \pm 620$ & $1020 \pm 830$ & $124 \pm 34$ & $47 \pm 40$ \\
\hline $\begin{array}{l}\text { chemostat } \\
\text { B2 }\end{array}$ & $22.4 \pm 5.4$ & $2.6 \pm 0.9$ & $\begin{array}{c}1.3 \pm 0.7 \\
(0.6 \pm 0.0)^{*}\end{array}$ & $19.8 \pm 5.5$ & $3240 \pm 790$ & $2280 \pm 800$ & $960 \pm 1120$ & $145 \pm 50$ & $49 \pm 58$ \\
\hline $\begin{array}{l}\text { mean of } \\
\text { chemostats } \\
\text { B1 and B2 }\end{array}$ & $23.8 \pm 5.3$ & $2.9 \pm 0.9$ & $\begin{array}{c}1.4 \pm 1.0 \\
(0.6 \pm 0.1)^{*}\end{array}$ & $20.9 \pm 5.4$ & $3170 \pm 670$ & $2180 \pm 710$ & $990 \pm 980$ & $134 \pm 42$ & $48 \pm 49$ \\
\hline
\end{tabular}

* Mean values from day 9 to day 15 .

crease of the TP concentration probably caused by the absorption of SRP on $\mathrm{CaCO}_{3}$ percipitates, which formed on the walls of the heating coil and the supply tubes of the chemostats. The phosphorus in the inflow and in the chemostat before inoculation consisted mainly of SRP, about $80 \%$ (Table 2). As soon as the bacteria began to grow, SRP decreased to $12 \%$ of the TP within three days. In addition to SRP, other dissolved phosphorus compounds were used by the bacteria, since TPF behaved similiar to SRP. After nine days the SRP concentration was $0.6 \mu \mathrm{g} \mathrm{P} \cdot \mathrm{l}^{-1}$ and 25 to $30 \%$ of the TPF. The TOC input in both bacterial chemostats was 2.5 and $2.9 \mathrm{mg} \mathrm{C} \cdot \mathrm{l}^{-1} \cdot \mathrm{d}^{-1}$, respectively, whereby about $65 \%$ of this carbon were mineralized by the bacteria. When the bacterial population decreased, neither TPF nor SRP, was released. In the chemostat inflow the C:P ratio of the particulate material was more than 550 . However, it decreased to 48 in the chemostats, because the concentration of the particulate phosphorus increased from 6.7 to $20.9 \mu \mathrm{g} \mathrm{P} \cdot 1^{-1}$, whereas the particulate organic carbon dropped from 3.82 to $0.99 \mathrm{mg}^{-1}{ }^{-1}$ (Table 2).

\section{Discussion}

The conditions in batch and chemostat cultures differ in many respects from the environmental conditions of a lake epilimnion. The phytoplankton community is reduced to one species and zooplankton has been excluded. The turbulence, induced by stirring and aeration, is greater than in situ turbulence and thus increases the availability of nutrients and oxygen to the bacteria and enhance their growth. Turbulence will also influence the distribution of dispersed and attached bacteria. At the beginning of a batch experiment the nutrient concentration may only be compared with in situ concentrations during the decay of heavy algal blooms. The growth of the bacterial population stops when either the substrate is exhausted or growth inhibiting metabolites accumulate. Thus, with respect to the nutrient supply, the batch system simulates the epilimnion to a much worse degree than does a chemostat culture. On the other hand, the bacterial growth in chemostats is controlled only by the chemostat dilution rate, whereas in lakes a combination of energy supply (which in most cases is independent of the lake hydraulics) and predation is efficient. In consequence, both systems can be used to study quantitative and qualitative aspects of the bacterial mineralization of algae, but mineralization rates obtained by experiments can only be used with great caution to draw conclusions concerning processes in lakes.

Heat treatment killed the algae immediately and caused a rapid increase of dissolved phosphorus, mainly SRP. Different methods of killing algae (UV, chloroform, heat) do not change the release rates of nutrients (Golterman, 1964). The role of added bacteria is most likely to be independent of the way the algae were killed. The slow death of Scenedesmus and Chlorella (DePinto \& Verhoff, 1977), when exposed to darkness, prevented the manifestation of a phosphorus release by autolysis, because the remaining viable algae and bacteria 
had taken up this phosphorus. In our batch cultures growing bacteria acted as additional consumers of the phosphorus released by the heat induced autolysis of algae. This $\mathbf{P}$ uptake was dependent on the C:P ratio of the algae (Table 1 ). However, when the bacterial population began to decrease because of shortage of energy, some phosphorus was regenerated. The chemostat experiments showed, that a continuous supply of energy (dead algae) prevented the decay phase of the bacterial population, and thus any net regeneration. Both processes, $\mathrm{P}$ uptake and $\mathrm{P}$ release, were temperature-dependent (Fig. 4). The transfer of phoshorus from dead algae to bacteria may occur in two different ways:

a) Most algal phosphorus is released by autolysis and subsequently taken up by dispersed bacteria, as shown in this study.

b) An observed fast phosphorus release could be an artifact, i.e. be the consequence of the heat treatment of the algae. The algal phosphorus is directly taken up by attached bacteria.

In both cases phosphorus in the epilimnion is finally released by the grazing activity of bactivorous zooplankton or by autolysis of the bacteria as a result of starvation. Because bacteria are very efficient in taking up phosphorus, and in this respect are superior to algae (Currie \& Kalff, 1984), it may be less important to know the exact mode of phosphorus transfer from algae to bacteria.

The question that remains is which parameters determine how much algal phosphorus is taken up by the bacteria? The phosphorus uptake by the bacteria during the time interval $\Delta t=\left(t_{2}-t_{1}\right)$ amounts to:

$\Delta \mathrm{P}_{\mathrm{B}}=\Delta \mathrm{C}_{\mathrm{B}} \cdot \frac{1}{\mathrm{~K}_{\mathrm{B}}}=\Delta \mathrm{C}_{\mathrm{s}} \cdot \mathrm{Y}_{\mathrm{c}} \cdot \frac{1}{\mathrm{~K}_{\mathrm{B}}}$

and the change of substrate phosphorus can be expressed as:

$\Delta \mathrm{P}_{\mathrm{S}}=\Delta \mathrm{C}_{\mathrm{S}} \cdot \frac{1}{\mathrm{~K}_{\mathrm{S}}}$ with $\Delta \mathrm{P}_{\mathrm{S}}<0$

where $P_{B}$ and $P_{S}$ are the phosphorus concentrations, $C_{B}$ and $C_{S}$ the carbon concentrations, and $K_{B}$ and $K_{S}$ the C:P ratios (by weight) of the bacteria and the substrate, respectively. The yield constant for carbon is $\mathrm{Y}_{\mathrm{c}}=-\Delta \mathrm{C}_{\mathrm{B}} / \Delta \mathrm{C}_{\mathrm{S}}$. The difference between the substrate change and the increase of bacterial phosphorus is:
$\Delta \mathrm{P}_{\mathrm{S}}+\Delta \mathrm{P}_{\mathrm{B}}=\Delta \mathrm{C}_{\mathrm{S}} \cdot\left(\frac{1}{\mathrm{~K}_{\mathrm{S}}}-\frac{1}{\mathrm{~K}_{\mathrm{B}}} \cdot \mathrm{Y}_{\mathrm{C}}\right)$

From equation (3) the relative measure $F$ for the amount of substrate phosphorus released in terms of substrate phosphorus transformed by the bacteria can be calculated:

$\mathrm{F}=\frac{\Delta \mathrm{P}_{\mathrm{S}}+\Delta \mathrm{P}_{\mathrm{B}}}{\Delta \mathrm{P}_{\mathrm{S}}}=\left(1-\mathrm{Y}_{\mathrm{c}} \cdot \frac{\mathrm{K}_{\mathrm{S}}}{\mathrm{K}_{\mathrm{B}}}\right)$

$F$ depends on the C:P ratio of both the bacteria and the substrate and on the yield $Y_{c}$ (Fig. 8). If $\mathrm{K}_{\mathrm{S}} / \mathrm{K}_{\mathrm{B}} \times \mathrm{Y}_{\mathrm{c}}>1$ then supplementary phosphorus is possibly taken up or the bacteria are forced to adapt their C:P ratio to the available phosphorus (Dicks \& Tempest, 1966). In the preceding consideration a homogeneous substrate was assumed. However, algae are a very complex mixture of phosphorus and carbon compounds which are partly resistent to decomposition. The relative amount of refractory phosphorus compounds increases with increasing C:P of the algae (Foree et al., 1970).

In the batch experiment an increase of the algal C:P ratio from 44 to 88 caused only a slight increase of the phosphorus taken up by the bacteria which contradicts equations (4). This may be due to a nitrogen limitation of the bacteria, as the N:P ratio (by weight) of the algae was only 3 .

- To summarize the algal and bacterial C:P

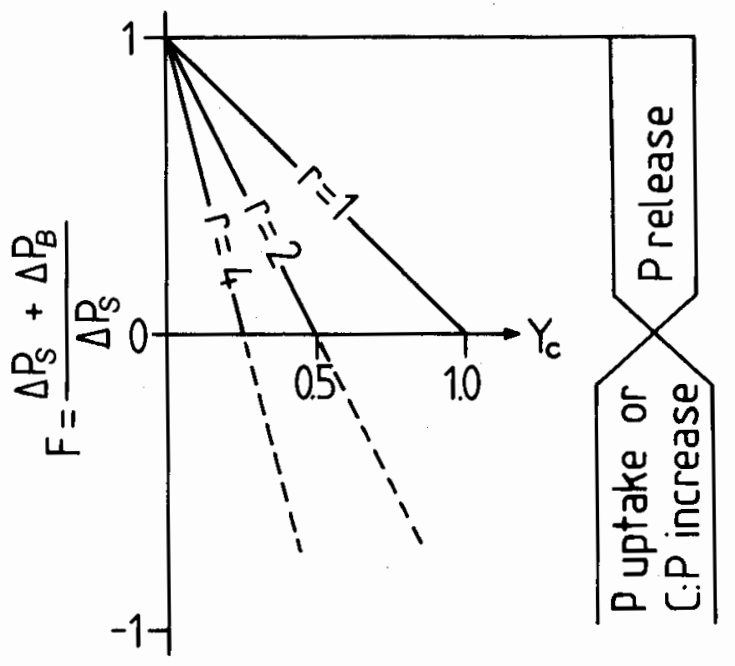

Fig. 8. The relation between phosphorus release, yield $\mathrm{Y}_{\mathrm{c}}$ and C:P ratios of substrate $\left(K_{S}\right)$ and bacteria $\left(K_{B}\right) ; r=K_{S} / K_{B}$. 
stoichiometry and the yield constant of carbon determine how much of the algal phosphorus is taken up by bacteria. An attempt is made to quantify these variables. From our chemostat experiment a $\mathrm{K}_{\mathrm{B}}$ of about 50 has been estimated. Stöckli (1985b), who worked with a natural bacterial population measured $a K_{B}$ of 70 for bacteria growing on excretion products of Chlamydomonas, and he estimated $a K_{B}$ of 147 for bacteria growing on dead Chlamydomonas cells. These values markedly exceed those reported in the literature which vary between 8 and 50 (Dicks \& Tempest, 1966; Bowen, 1966; Morowitz, 1968; Schlegel, 1969). It was not possible to get in situ values for $\mathrm{K}_{\mathrm{B}}$, because it is difficult to separate bacteria from detritus. In cultures, the $C: P$ ratio $K_{S}$ of algae varied between 23 and 375 (Uehlinger, 1980; Gächter \& Bloesch, 1985). Again the C:P ratio of natural phytoplankton can only be estimated by measuring the C:P ratio of seston (to which algae contribute only a minor fraction). In several Swiss lakes the epilimnetic seston $C: P$ ratio varied between 30 and 190 (Gächter \& Bloesch, 1985). The yield constant $Y_{\mathrm{c}}$ of several defined substrates was 0.33 to 0.83 (Payne, 1971). Assuming all particulate organic carbon be fixed in bacterial biomass, a maximum $Y_{c}$ of 0.16 can be estimated from our chemostat experiment, but we have to consider that the composition of Chlamydomonas, and therefore $\mathrm{Y}_{\mathrm{c}}$, may not be representative for a natural phytoplankton community. Because $K_{B}, K_{S}$ and $Y_{c}$ vary within a broad range and corresponding field data are not available, a statement, to what extent bacteria contribute to the epilimnetic phosphorus regeneration is still speculative. If a $\mathrm{K}_{\mathrm{B}}$ of 50 , a mean of $\mathrm{K}_{\mathrm{S}}$ of 120 and a $Y_{c}$ of 0.2 to 0.4 are taken, then $15 \%$ to $30 \%$ of the algal phosphorus would be released by the bacterial activity or remain in the medium, respectively.

\section{Conclusion}

The bacterial mineralization of algal carbon is linked with no or minor phosphorus release. If an energy source, such as algal exsudates or autolysis products, is available, phosphorus is incorporated in bacterial biomass. $1 \mathrm{mg}$ algal carbon (dead cells or algal filtrate) immobilizes 6 to $14 \mu \mathrm{g}$ phosphorus. Bacteria should be considered to be consumers rather than regenerators of phosphorus in the epilimnion.

\section{Acknowledgements}

I am indepted to Dr J. Bloesch for useful discussion and criticism, and Drs G. Hamer, J. Zeyer and A. Stöckli for reviewing the manuscript. This work was supported by the Swiss National Foundation for Scientific Research, project 3.762-0.76.

\section{References}

Bloesch, J., P. Stadelmann \& H. Bührer, 1977. Primary production, mineralization and sedimentation in the euphotic zone of two Swiss lakes. Limnol. Oceanogr. 22: 51-526.

Bührer, H., 1979. Der Einfluss von Kohlenwasserstoffen auf die Oekologie der Bakterien im aeroben Seesediment. Schweiz. Z. Hydrol. 41: 315-355.

Bowen, H. J. M., 1966. Trace elements in biochemistry. Academic Press, N.Y.

Currie, D. J. \& J. Kalff, 1984. A comparison of the abilities of freshwater algae and bacteria to acquire and retain phosphorus. Limnol. Oceanogr. 29: 298-310.

DePinto, J. V. \& F. H. Verhoff, 1977. Nutrient regeneration from aerobic decomposition of green algae. Envir. Sci. Technol. 11: $371-377$.

Dicks, J. W. \& D. W. Tempest, 1966. The influence of temperature and growth rate on the quantitative relationship between potassium, magnesium, phophorus and ribonucleic acid of Aerobacter aerogenes growing in a chemostat. J. gen. Microbiol. 45: 547-557.

Foree, E. G., W. J. Jewell \& P. L. McCarty, 1970. The extent of nitrogen and phosphorus regeneration from decomposing algae. In S. H. Jenkins (ed.), Advances in Water Pollution Research 2. Pergamon Press, Oxford: III $-27 / 1-27 / 15$.

Gächter, R. \& J. Bloesch, 1985. Seasonal and vertical variation of the $C / P$ ratio in suspended and settling seston of lakes. Hydrobiologia 128: 193-200.

Golterman, H. L., 1964. Mineralization of algae under sterile conditions or by bacterial break down. Verh. int. Ver. Limnol. 15: $544-548$.

Golterman, H. L., 1973. The role of phytoplankton in detritus formation. Mem. Inst. Ital. Idrobiol. 22 suppl.: 89-103.

Hirsbrunner, M., 1981. Chemostatanlage zur kontinuierlichen Kultur von Algen. Schweiz. Z. Hydrol. 43: 370-376.

Johannes, R. E., 1968. Nutrient regeneration in lakes and oceans. In M. R. Droop \& E. J. F. Wood (eds), Advances in Microbiology of the the Sea, 1. Academic Press, Lond.: $120-132$.

Morowitz, H. J, 1968. Energy flow in Biology. Academic Press, N.Y.

Overbeck, J., 1974. Microbiology and chemistry. Mitt. int. Ver. Limnol. 20: 198-228.

Overbeck, J., 1977. Praktikumsanleitung für den LimnologieKurs, 7. Semester. Max Planck-Institut Plön, W. Germany: 27-29. 
Reichardt, W., 1971. Catalytic mobilization of phosphate in lake water and by Cyanophyta. Hydrobiologia 38: 377-394.

Reichardt, W., 1978. Einführung in die Methoden der Gewässermikrobiologie. Gustav Fischer Verlag, Stuttgart.

Payne, W. J., 1970. Energy yields and growth of heterotrophs. Ann. Rev. Microbiol. 24: 17-52.

Peters, R. H. \& F. H. Rigler, 1973. Phosphorus release by Daphnia. Limnol. Oceanogr. 18: 821-839.

Plüss, S., 1978. Populationsdynamik der Bakterienflora im hocheutrophen Greifensee. Diplomarbeit, ETH-Zürich.

Schlegel, H. G., 1969. Allgemeine Mikrobiologie. Georg Thieme Verlag, Stuttgart.

Staub, R., 1961. Ernährungsphysiologisch-autökologische Untersuchungen an der planktischen Blaualge Oscillatoria rubescencs D. C. Schweiz. Z. Hydrol. 23: 82-198.
Stöckli, A., 1985a. The role of bacteria and algae in phosphorus regeneration using linked continuous cultures. Verh. int. Ver. Limnol. 22: $2773-2779$.

Stöckli, A., 1985b. Die Rolle der Bakterien in der Regeneration von Nährstoffen aus Algenexkreten und Autolyseprodukten. Doct. Thesis, Swiss Fed. Inst. Technol. (ETH), Zürich.

Uehlinger, U., 1981. Experimentelle Untersuchungen zur Autökologie von Aphanizomenon flos-aque. Arch. Hydrobiol. Suppl. 60 (Algological Studies 28): 260-288.

Vogler, P., 1965. Beiträge zur Phosphoranalytik in der Limnologie Fortschr. Wasserchemie Grenzgeb. 2: 109-119.

Received 22 April 1985; in revised form 16 December 1985; accepted 6 February 1986. 